\section{A word from the President}

Wow! What a conference! The 28th Annual CHLA / ABSC Conference was held in St. John's, Newfoundland and Labrador, 14-18 May 2004. We saw unmistakable evidence that hard work and dedication by a very small group "On the Edge" of Canada can put together an outstanding program that was informative, entertaining, and efficiently run. From Sister Elizabeth Davies and Dr. Bill Eaton, to puffins and port, we were inspired, challenged, and entertained. Congratulations to George Beckett and the Conference planning team.

The Conference was a great place to get together to discuss ongoing projects like the National Network of Libraries for Health / Réseau national des bibliothèques pour la santé (NNLH / RNBS). In Newfoundland and Labrador, a group of supporters suggested that health libraries put a link to the NNLH / RNBS on their home pages. The Board endorsed that effort, and Tim Tripp, Director of Public Relations, created a page where the NNLH / RNBS logo can be downloaded (http://www.chla-absc.ca/nnlh/support.html). The Board agreed to continue the Task Force's mandate for two more years, and to ensure that there is Canada-wide geographic representation on NNLH / RNBS, Charlotte Beck, who hails from Vancouver and is also Secretary on the CHLA / ABSC Board, agreed to serve on the Task Force. The Board also agreed to provide what funds it can to support a stakeholder meeting to be held in the fall of 2004. Results from that meeting will add to the evidence of the need for a national network. There is a lot of momentum for this initiative, as evidenced by the great turnout at the session in Newfoundland and by the interest shown from groups like the Canadian Cochrane Centre. This effort is a weighty one, and we owe a debt of gratitude to the Task Force members: Liz Bayley, Charlotte Beck, Patrick Ellis, Jim Henderson, Jessie McGowan, and Hélène Valin from Health Canada.

\section{Journal news}

This is the third issue of the electronic-only Journal of the Canadian Health Libraries Association / Le journal de l'Association des bibliothèques de la santé du Canada (JCHLA / JABSC). Karen Neves and the editorial team have worked hard to ensure that the high quality of content continues. At the same time, they have been dealing with the technical challenges of providing access to members and institutions. Membership categories have new relevance for ejournal access. Access by IP range is available only to institutions, and you must pay the institutional rate to have access by IP. These "little" things are very big ones, and we have had excellent cooperation from our partner NRC Research Press in working out the kinks.

The Board has been wrestling with ways to keep the revenue stream from the journal but still work toward an "open access" model. The current year of the journal is available only to paid members of CHLA / ABSC. A task force is looking at different models for sponsorship and advertising that will take advantage of the electronic journal format, and we hope that we may in the future be able to adopt the Medical Library Association model of journal content that is freely available to all.

\section{Interest groups}

For those of you who have attended the last two CHLA / ABSC conferences, you may have met Hakim Bishawi from the United Arab Emirates. Hakim has been an enthusiastic participant at the conferences, and he suggested that there should be a way for people outside Canada to work together in affiliation with CHLA / ABSC. According to the CHLA / ABSC Bylaws, Article V (1.) a group of persons "residing in a particular community or geographical area of Canada", can form a Chapter, but we had no mechanism for people living outside Canada. The Board accepted Hakim's challenge to find a way for people outside of Canada to participate and has agreed to the following Terms of Reference for Interest Groups:

\section{Guideline for CHLA / ABSC Interest Groups}

CHLA / ABSC Interest groups are informal groups of CHLA / ABSC. The purpose of the Interest Group is to allow members of CHLA / ABSC who have a common interest in an aspect of Health Librarianship not covered by other committees and task forces, to meet, correspond, and discuss that common interest.

Each Interest Group must have a Convenor. The Convenor is elected by members of the Interest Group at least every 2 years. The Interest Group may adopt other structures as determined by the members of the Group. Each Interest Group must have Terms of Reference, Goals, and a statement about membership.

Any member may organize an Interest Group by contacting the CHLA / ABSC President. The President will bring the request to the Executive for approval.

Interest Groups are provided with meeting space during the annual conference, space on the Association's Web page, and space in the Association's journal to communicate Interest Group news.

All CHLA / ABSC members in good standing may belong to an Interest Group. An Interest Group must have a minimum of three (3) members to gain the support of the Association. There is no limit to the number of members who may belong to an Interest Group.

The Board hopes that this will encourage international groups as well as groups who come together on specific issues. Many thanks to Hakim for this excellent idea!

\footnotetext{
${ }^{1}$ BY-LAWS, as amended through 2003 [online]. Available from: http://www.chla-absc.ca/documents/chlabylaws2003.pdf [cited 12 June 2004].
} 


\section{Volunteer policy}

At the Conference in Newfoundland, one of the contributed papers was "Ontario hospital library managers' attitudes to volunteers" by Mary McDiarmid and Ethel Auster. CHLA / ABSC funded Mary's research through a Chapter Initiative Grant to the Central Ontario Health Libraries Association. In the fall of 2003, Mary made a presentation to the CHLA / ABSC Board with her results. As a result of the findings, the Board struck a Task Force to develop a Policy on Volunteers in Health Sciences Libraries. The Volunteer Task Force members were Andrea Kuttner, Penny Logan (Co-chair), Mary McDiarmid, Jessie McGowan (Co-Chair), Elyse Pike, Ruth Rochlin, and Jeannette Smit. The Draft version of the Policy is being circulated to the membership at press time. The following is a draft of the Policy:

\section{CHLA / ABSC Library Volunteer Policy 2004}

\section{Policy}

Volunteers have an important role in health sciences libraries and patient education libraries, and, when used appropriately, are welcome additions to a library. Volunteers are unpaid and give of their time and talents to support the library and its services. Volunteering in a health library is an excellent opportunity for those wishing to experience the library culture or for those looking for work experience. Volunteers can be enthusiastic advocates for the library within the institution and in the larger community. The role of the volunteer in a health care setting is to support the work of paid staff. In keeping with typical health institution volunteer policies that prohibit volunteers from performing professional or technical procedures, volunteers are not responsible for the usual work of paid library staff.

\section{Guidelines}

- It is imperative that library volunteers should only be engaged when it is clear to both administration and labour unions that they are only supporting paid workers and are not replacing them.

- Library volunteers require ongoing training and library staff must be aware of the commitment that is needed both in time and materials to ensure volunteers are well equipped to carry out their assigned tasks.

- Prior to placement in the library, all the existing paid library staff must endorse the use of volunteers in the library.

- There will be a well-defined written position description that outlines the activities that a volunteer is asked to perform.

- The position description adequately describes the physical demands and technical expertise that are necessary in order to fulfill the requirements of the position.

- Recognizing that volunteer duties are often assigned with the individual's unique skills and limitations in mind, it is within the library manager's discretion to revise the written requirements of the position upon interviewing the volunteer candidate.

- A copy of the revised position description will be given to the volunteer upon placement in the library.

- Whether or not the staff in the library is unionized, the institution's union representing clerical positions should review each volunteer position description to ensure that work that is part of the union's bargaining unit is not included.

- Library managers may obtain volunteers for the library through the institution's volunteer coordinator or from outside sources. Library managers may accept volunteers for the library on the recommendation of the volunteer placement coordinator; alternately, library managers themselves should have the authority to recommend to the volunteer placement coordinator potential volunteers for the library. Whether first selected by the volunteer placement coordinator or the library manager, potential library volunteers must participate in the institution's volunteer screening process, which may include a background check.

- Prior to placement in the library, the library's manager will interview the potential volunteer in order to assess their suitability, even though the volunteer placement coordinator may have conducted the initial interview.

- In the screening interview the library manager needs to clarify the library's expectations for the volunteer role including the time commitment required by the volunteer.

- The manager also needs to explore the volunteer's motivation, skills, and expectations to ensure they are compatible with the library's needs.

- It is most important in selecting a library volunteer that they are well matched with the position description.

- One paid staff library member must be assigned to supervise and manage the activities of the library volunteer.

- In order to ensure that paid staff and volunteers are treated consistently and fairly, volunteers must be held accountable to the institutional policies and procedures that are applicable to their placement and that are in force for all paid employees.

- The library volunteer's supervisor should maintain a record of the volunteer's attendance and performance. The supervisor should address any performance problems immediately.

- If a volunteer's performance has been substandard and has not improved in spite of coaching, the library volunteer's supervisor should seek the advice of the institution's volunteer placement coordinator.

- The contribution of library volunteers should be recognized either formally through existing institution employee recognition programs or through library initiated events.

Board members for 2004-2005 are Laurie Scott, Past President; Tamsin Adams-Webber, Vice President/President Elect; Charlotte Beck, Secretary; Joan Leishman, ACMC Representative; and three members who have graciously agreed to serve for a second term: Caren Mofford, Treasurer; Tim Tripp, Public Relations Director; and Judy Inglis, CE Coordinator.

Our editorial team members are Andrea Hodgson, who takes on the role of Past Editor; Karen Neves, Editor; and Rebecca Zakoor, Assistant Editor. Many thanks to all the members of the Board, the Editorial team, and the Task Force groups who work long and hard but always with good cheer.

Because of editorial deadlines, I am writing this as summer is just beginning, but it will make print in the fall. I wish you all a restful but interesting summer!

\section{Penny Logan}

